\title{
実時間マイクロVR カメラの試作
}

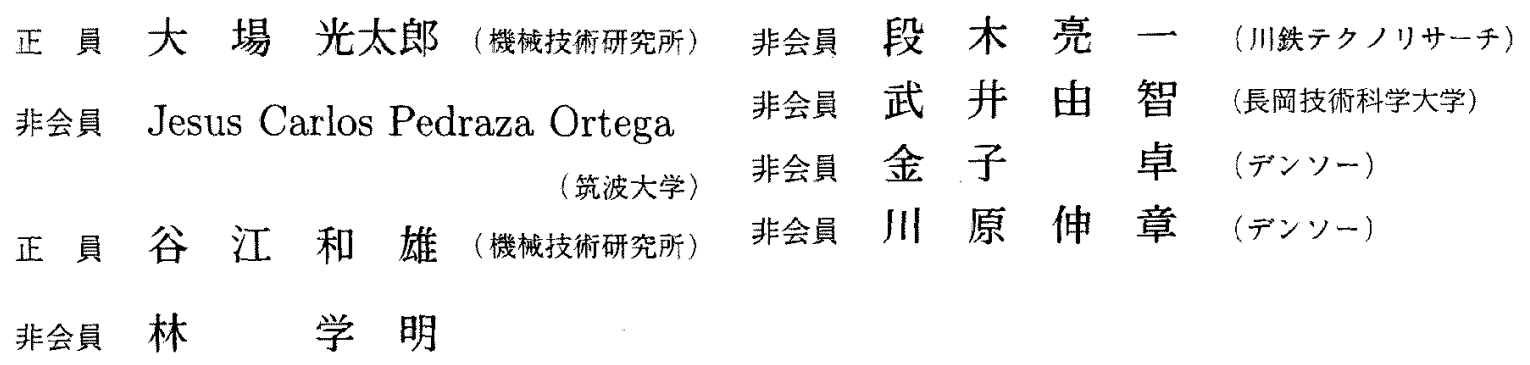

(デルフトハイテック $)$

Implementation of Real Time Micro VR Camera

Kohtaro Ohba, Member (Mechanical Engineering Lab.), Jesus Carlos Pedraza Ortega, Non-member (University of Tsukuba), Kazuo Tanie, Member (Mechanical Engineering Lab.), Gakuyoshi Rin, Non-member (DHT Corp.), Ryoichi Dangi, Non-member (Kawasaki Steel Techno-Research Corp.), Yoshinori Takei, Non-member (Tokyo Institute of Technology), Takashi Kaneko, Non-member, Nobuaki Kawahara, Non-member (Denso Corp.)

In this paper, a real time virtual reality camera system for the micro environments has been developed with a dynamic focusing lens and a smart vision sensor using the "depth from focus" criteria.

In the operation with a microscope, such as the micro-surgery, DNA operation and etc., the small depth of a focus makes bad controllability to actuate $3 \mathrm{D}$ micro objects with actuators. For example, if the focus is on the object, the actuator could not be seen in the microscope. On the other hand, if the focus is on the actuator, the object could not be observed. In this sense, the "all-in-focus image" is useful for the actuation in micro environments. However, one drawback on the all-in-focus image is that there is no information about the depth of objects. It is also important to reconstruct the micro $3 \mathrm{D}$ environments in real time to actuate the object with the micro virtual environments.

This paper discusses the criteria of "depth from focus" to achieve the all-in-focus image and micro 3D reconstruction, simultaneously. Then, a micro VR camera system has been developed to achieve the micro VR environments with the "depth from focus" criteria, i.e. the combination of the all-in-focus image and the micro 3D reconstruction. This system is constructed by a dynamic focusing lens, which can change the focus in high frequency, and a smart vision system, which is capable in capturing and processing the image data in high speed with SIMD architecuture.

キーワード : Depth from Focus, All-in-Focus Image

\section{1.はじめに}

近年, マイクロマシン環境における作業として, 顕微鏡画 像を誢きながらの細胞やDNA 操作が求められている。し かしながら顕微鏡画像の様に被写体深度が浅い光学系では， 物体に焦点を合わせるとアクチュエータに焦点が合わず，逆 に、アクチュエータに焦点を合わせると物体に焦点が合わ
ないという例が多く見受けられる。

例之ば图.1には，実際心通産省機械技術研究所で $5 \mu \mathrm{m}$ 程 度のガラス玉を積み重的三次元構造物を菁築する際の顕微 鏡画像の例を示している（a）の一つ目のガラス玉に焦点の 合わせた場合には，ほば同じ位置手前にある二つ目のガラ ス玉を呞んだグリッパはボケて見えず，逆に，(b)の二つ目 の玉とグリッパに焦点を合わせた場合は，一つ目のガラス 


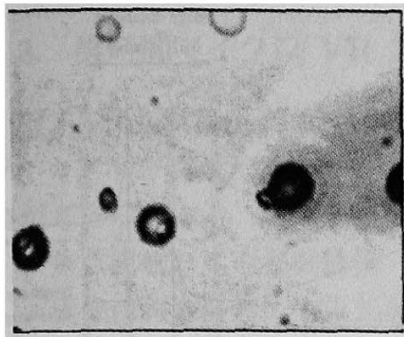

(a)

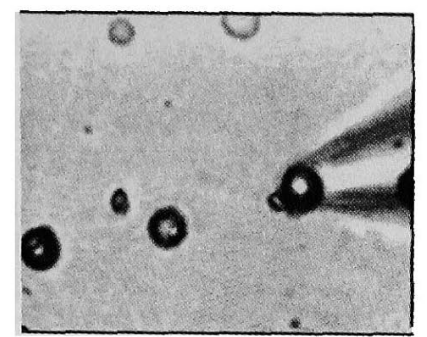

(b)
図 1 マイタロ環境下での操作例.

Fig. 1. Microscope Actuation with Micro Image.

玉が見えない様子を示している。

このような劣悪な視認性環境下においては, 熟練者が顕 微鏡の焦点距離を手動で動かしながら頭の中で物体の三次 元的形状を構築し，操作器を用いて物体を操作する事を強い られる.しかしながら, 超微細加工技術やマイクロサージェ リのための Human Machine Interface (HMI) として, 微 視的な環境を作業者に理解し易い形で提示するシステムは， その操作性・精度と作業効率を向上させる利点から, 必要 性が高まっている。

ここで試作しようとしているマイクロVRカメラシステ ムは,これらの顕微鏡画像の問題を解決するため, 実時間で どこでもピントの合った画像 (全焦点画像) と, 対象物体の 三次元的なプロファイルを生成・表示する事を目的とする。 全焦点画像と三次元プロファイルを同時に得る事により, 対 象物体を詳細に観測する事が可能となると同時に, 対象物 体を希望の視点から観測する事を可能とする.

ここで環境の三次元モデル構築手法をまとめると, 以下 の様な手法が提案されている(1).

-三角測量

- Focus

- 光波干涉

- Time of Flight

- 回折

- 偏光

それぞれの手法には計測原理に依存する特徵がある。例え ば三角測量では, 二つ以上のカメラもしくは能動的光源を 用い，一般環境をモデリングする事を可能としているが，そ れぞれの装置のキャリブレーションが必要であることと, 顕 微鏡のような被写体深度の浅い環境には適用が不可能であ る事が上げられる。

前述のような顕微鏡画像の場合, “被写体深度の浅さ”問 題は操作性に大きな問題を与えることを論じたが，これは同 時に三次元モデリング手法の一つである "depth from focus (defocus)” 手法を実現するためには大きな利点であると言 える.

そこで本論文では，マイクロマシン環境における操作性 を高める事を目的とし, "depth from focus" 理論 (2) (3) (4)

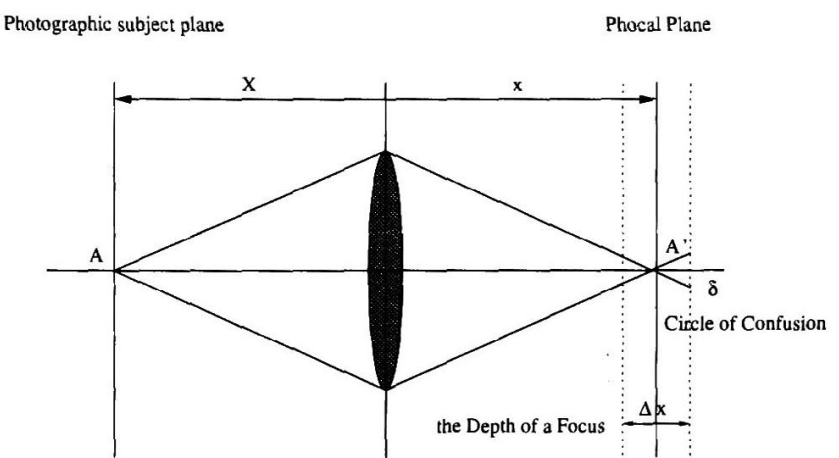

(a) The Depth of a Focus

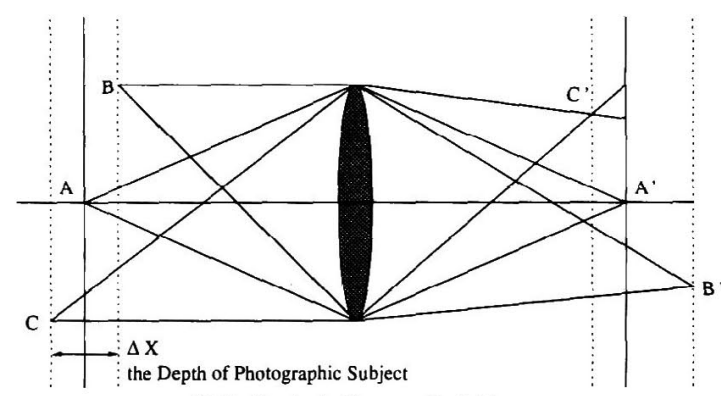

(b) The Depth of a Photographic Subject.

図 2 "Depth of a Focus" と "Depth of a Photographic Subject".

Fig. 2. "Depth of a Focus" and "Depth of a Photographic Subject".

(5)(6)により，寒時間でマイクロ環境を三次元モデリングす ると同時に物体表面の全焦点画像 (7) (8)を獲得するカメラシ ステムの構築を試みる. 現在まで, 同様の顕微鏡システムは 期待され各社から試作されているが，実時間での実現は行 なわれていない.ここではまず,“depth from focus”理論を 紹介し, 次に, 実時間 VRマイクロカメラの試作を行なうに 当たっての問題点の検討を行ない, システムの検証を行な う.ここで用いる可変焦点機構は, 別途, 株式会社デンソー により試作された“可変焦点レンズ”(9) (10)を適用する。 ま た高速画像処理機構は, 通常の画像処理システムはビデオ フレームレート (30 frame/sec.)をベースとした画像取り 込みに規制される事から，C-MOS ビジョンチップ(11)(12) である IVP 社スマートセンサ MAPP2200(13)を用いる。

\section{2. "Depth from Focus" 理論}

$\langle 2 \cdot 1\rangle$ "Depth from Focus" のための光学理論 “depth from focus" 理論は, 光学的に対象物体に焦点の 合う範囲から対象物体の形状を計測する手法である (2) (3) (4) (5) (6).

あるレンズ系において，像が結像した場合には以下の式 が成り立つ。

$$
\frac{1}{x}+\frac{1}{X}=\frac{1}{f}
$$

この式はガウスのレンズ法則として知られ,$x$ と $X$ は,レン

電学論 $E, 120$ 巻 6 号, 平成 12 年 
ズからの対象物体までの距離 (以後, 物体距離) とレンズか ら結像面までの距離 (以媛, 画像距離) であり，fがレンズ の焦点距離である。

光学的には，図.2に示すように (a) 焦点深度と (b) 被写界 深度があり，一般的に混同されている事からここではそれ らの明確な区別を行ないたい。

焦点深度 (The Depth of a Focus) 焦点深度 $\Delta x$ は，撮像面において前後に多少ずれていてもピントの合っ ている(ボケが認められない)範围を意味し，撮像素子もし くは肉眼の分解能に関係しており, 図 2(a)の幾何学的な関

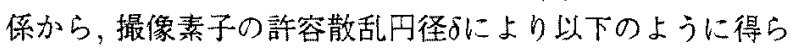
れる(15).

$$
\begin{aligned}
& \text { 然限遠の時: } \Delta x=2 \delta \frac{f}{D^{2}}, \\
& \text { 有限遠の時: } \Delta x=2 \delta \frac{X}{D^{\prime}},
\end{aligned}
$$

ここで $D$ と $D^{\prime}$ はそれぞれレンズ直径と絞りである.

被写界深度 (Depth of a Photographic Subject) 一方, 被写界深度 $\Delta X$ は, 物体面において前後に物体面が多 少ずれてもピントの合っている許容距離の事を意味し，図 2(b) から，次式が得られる(15).

$$
\Delta X=\frac{2 \delta X f D(X-f)}{f^{2} D^{2}-\delta^{2}(X-f)^{2}} .
$$

この式から, 被写界深度は焦点距離 $f$ と物体との距離 $X か ゙$ 関係している事が分かる，ここで，被写界深度はレンズ方 向手前に浅く，奥行き方向に染くなる性質を持つがここで は，手前方向と奥行き方向を足し合わせ被写界深度 $\Delta X$ を 定義している事に注意したい。

一般的に, 画像距離 $x$, 物体距離 $X$ ，もしくは焦点距離 $f$ (以後, 光学距離) を変えながら撮像した一連の画像列か ら最も焦点の合った画像を選び出し，その時の物体距離 $X$

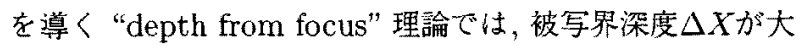
きい場合，光学的に物体の奥行き判断が困難であると同時 に，焦点深度 $\Delta x$ が大きい場合，一連の画像列に明らかな焦 点の鮮明度の違いが明確でない事から測定誤差を大きく含 む可能性がある事に注意したい。このことは，焦点深度の式 (3)において, 物体距離 Xが大きくなると焦点深度が大き くなると同時に, 被写界澡度においても, 受光素子の認識で

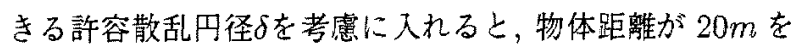
越えた場合には通常のレンズと CCD 受光素子では測定が 困難である事が知られている(16).

また，被写界深度はカメラの絞り(レンズ直径)に大きく 影響している事が容易に理解できる、例えば，絞りを絞ると 被写界哚度は深くなり，逆に絞りを解放すると被写界深度 は浅くなる．内視鏡などではこの原理を用い,なるべく絞り を絞り被写界深度を媣くして撮影を行なっているが，十分 な感度で撮像するためには強い光源が必要である，本論文 ではこの皎りの影響については樑く議論せず，絞りがどの ような状況でも全焦点画像を獲得する事を目的とする。

以上の事から, depth from focus 理論は，顕微鏡などの

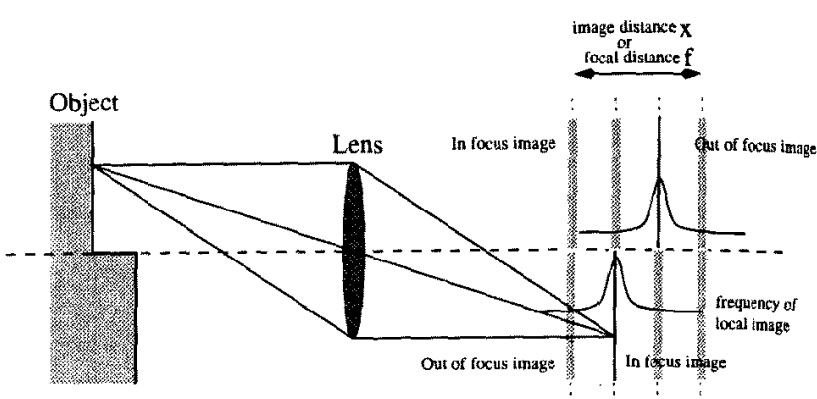

図 3 "Depth from Focus" 理論.

Fig. 3. Concept of the "Depth from Focus".

物体距離の小さい光学システムにおいては, 焦点深度, 被写 界深度とも極端に小さくなる事から，非常に有用な理論で ある。

〈2·2〉 全焦点画像と奥行き画像の獲得 "depth from focus" 理諭を用い，全焦点画像と奥行き画像を獲得する手 法图.3に示す，基本的には，ある画像内の位置で，光学距

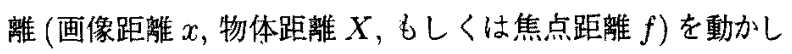
ながら画像の局所空間周波数分析を行ない, 周波数がピー クの焦点距離がピントの合ったところである事から, 全焦点 画像はそれぞれの焦点距離での焦点の合った部分の張り合 わせで表され，同時に奥行き画像はそれぞれの部分での焦 点の合った所での物体距離 $X$ から得る事が可能である。っ まり, 光学距離を動かしながら撮像した椱数の画像から良 い所 (合焦点部分)だけを寄せ集めて全焦点画像を作成し，

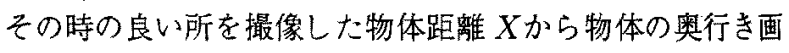
像を生成する。

本論文では, 各画素の局所空間周波数分析は, 画像濃淡値 の空間的な分散で評価するものとし，次式の Image Quality Measure (IQM) :定義する(14).

$$
I Q M=\frac{1}{|D|} \sum_{x=x_{1}}^{x_{f}} \sum_{y=y_{1}}^{y_{f}}\left(\sum_{p=-L_{c}}^{L_{c}} \sum_{q=-L_{r}}^{L_{r}}\{(x, y)-I(x+p, y+q)\}\right)
$$

ここで領域 $\left(-L_{c}, L_{c}\right)-\left(-L_{r}, L_{r}\right)$ と $\left(x_{i}, x_{f}\right)-\left(y_{i}, y_{f}\right)$ はそれぞれ，分散評価上平滑化を行なうための小領域であ る、また，Dは画素単位で正規化するための評価を行なうす べての画素数である。したがって, 焦点距離を動かしなが らIQMの值をそれぞれの画素毎もしくは領域毎に評洒し， IQM 值のピークを検出し，その時の画素濃淡値 $I$ と画像距 離 $x$ 加算出した物体距離 $X$ を，それぞれの画素位置に対 応するマトリクス要素にそれぞれ代入する。この処理をすべ ての焦点距離について行なった後, それぞれのマトリクス が，全焦点画像と奥行き画像に相当する。

この手法は，単眼で全焦点画像と奥行き画像を獲得可能 で, 複数カメラのキャリブレーションも必要としないもの である事から，顕徽鏡映像などへの応用には非常に適した 手法であると言える。 


\section{3. 実時間マイクロ VR カメラ}

前述の “depth from focus” 理論を用い, 実時間マイクロ VR カメラを実現するための大きな問題点としては次の二 点が考えられる.

- 焦点距離の高速移動機構

・画像情報の高速入力・処理システム

ここで目的としている実時間性とは, 1 秒間に 30 枚の出力 画像を生成する事である. そこで, 本節では以上の二点につ いてそれぞれ解決し，実時間マイクロVRカメラシステム の構筑を目指す。

〈3・1〉可变焦点レンズシステム＼cjkstart前述の仕様を満たす 実時間 VR カメラを実現するためには，最終的に $30 \mathrm{~Hz}$ 光学距離を変える必要がある. 従来の同様な目的のための 䫓微鏡システムが採用している, 物体位置, 光学的機構もし くは撮像面を高速で垂直方向に並進移動し，それぞれ物体 距離, 画像距離, 焦点距離を变える手法は, 機構自体の持つ ダイナミクスから実時間性にそしい，そこでここでは，別 途, 金子らの試作した, PZT バイモルフアクチュエータと ガラスダイアフラムにより構築された可変焦点レンズを用 いる(9) (10).

可変焦点レンズの概形と構成を図.4, 図.5にそれぞれ示寸， このレンズは PZT バイモルフに印加する電圧を変える事 により，図6にに示すように，凸レンズから凹レンズまで変 化する事が可能である. 電圧を印加しない場合は平板ガラ スとなる，金子らの実験によると， $150 H z$ 程度まで位相が 遅れずに周波数応答に対応する事が検証されている。詳細 は(9)(10)を参考にされたい. 我々は，この可変焦点レンズを 市販のマクロズームレンズ (Asahi co. MZ-30, $\mathrm{f}=27.2$ 58.5mm, F7.5)の先端に取り付ける事により, マクロズー ムレンズの本来の光学特性 (焦点距離) を高速に前後に振る 可変焦点機構を実現した.

またここでは, 物体距離 $X$, 画像距離 $x$ を動かして全焦 点画像を得る手法とは異なり, 焦点距離 $f$ 自体を動かしな がら全焦点画像と奥行き画像を獲得する手法である事に注 意したい. 焦点距離を動かす事により, 画像の大きさは変化 するものの, 今回用いた画像の倍率と測定レンジでは, 画像 の大きさの変化は十分無視できるものである事が確認され た事から，本論文では画像の大きさの補正は行なわず，実時 間性の実現に専念することとする。

〈3.2〉高速画像入カ・処理システム通常の画像処理 システムは, カメラからの NTSCビデオ信号を一つの ADC で逐次取り込み画像デー夕を PC内のメモリーに構筑する ものであるため, インターレースのビデオ信号を用いても， フレームレート $60 \mathrm{frame} / \mathrm{sec}$.以上での取り込みは不可能 である。

近年, 画像入力·処理を高速化する事を目的として,ビジョ ンチップの開発が行なわれている. 中でも画像デバイス上 の任意の部分を読み込める C-MOS ビジョンチップの開発 が盛んに行なわれている(11)(12)。これらのビジョンチップ

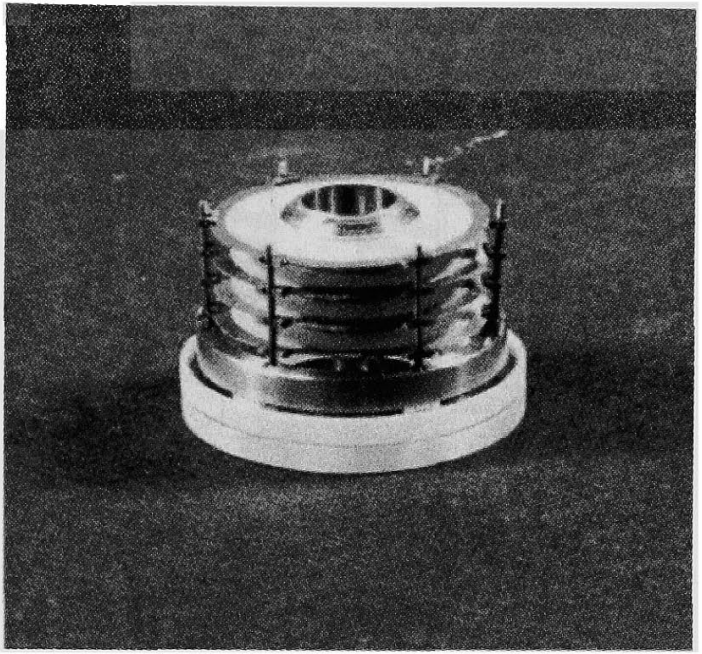

図 4 可変焦点レンズ概観.

Fig. 4. Photo of Dynamic Focusing Lens.

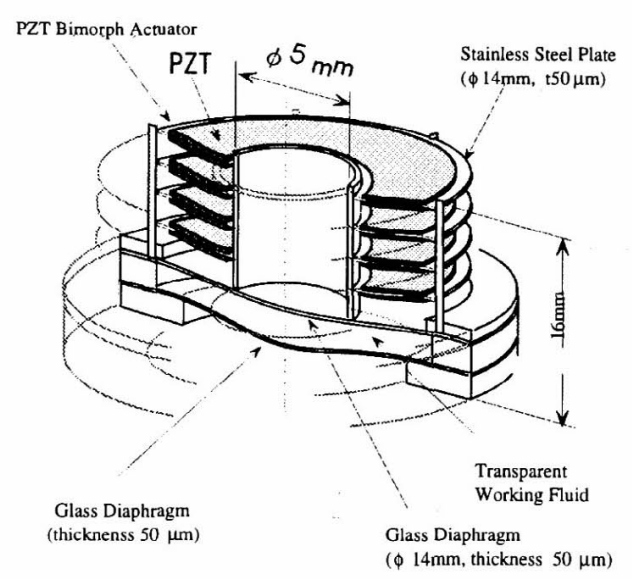

図 5 可変焦点レンズ機構.

Fig. 5. Schematic View of Dynamic Focusing Lens.

の構成としては, 以下のようなものがある.

(1) Single ADC Architecture

(2) Column Parallel ADC Architecture

(3) Pixel Parallel ADC Architecture

(1)のタイプのものは PCベースのビジョンシステムであり, 十分なデー夕転送の帯域が確保できない問題がある。(2), (3) は, 画像情報を並列に取り込み・処理が行なえる事から デー夕転送帯域・処理能力は高い. 特に (3) は, 処理自体は 超並列処理である事からデー夕転送・処理とも高速である が，まだ試作の域を越えていないため，十分な画像解像度を 確保する事が困難である.

そこで, 今回は図.7に示す, IVP 社製 C-MOS ビジョン チップ (MAPP2200)を用いる ${ }^{(13)}$.このシステムは, 解像度 


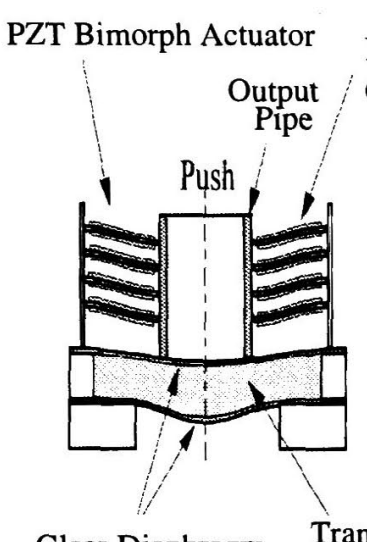

Glass Diaphragm

(a)Convex Lens

図 6 可変焦点機構原理.

Fig. 6. Principle of Dynamic Focusing.

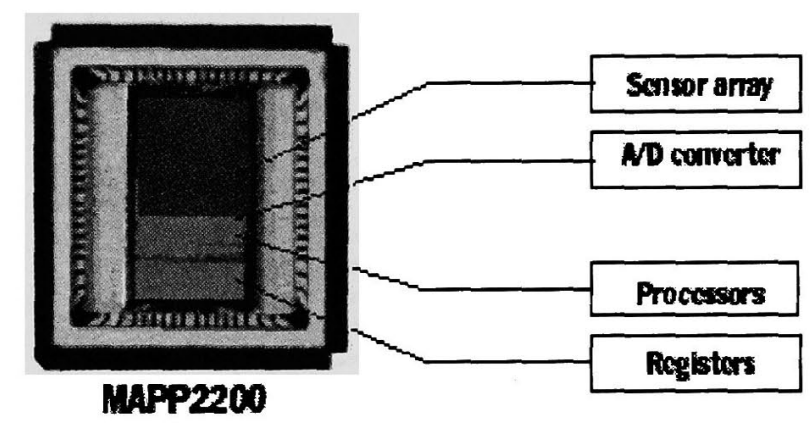

図 7 MAPP2200.

Fig. 7. MAPP2200.

$256 \times 256$ で, ADC とシフトレジスタが 256 個並列に付い ており，256 画素データの並列取り込みが可能である. また 内藏の DSP は SIMD(Single Instruction Multiple Data stream) 処理が可能なものである.プログラム開発は DSP 様のアセンブラ言語, もしくは, WindowsNT 上の MS Visual $\mathrm{C}++$ でライブラリを呼び出す事で処理が可能である. ここでは式 (5)の IQM を計算するためには, SIMD 処理を DSP アセンブリにより構築した.

〈3.3〉 全体システム スマートカメラ MAPP2200に 可変焦点レンズシステムを取り付けたシステム概観を図.12 に示す. 可変焦点レンズは, PCの DACにより amp. を通 して制御し, 画像情報はスマートセンサ内部の DSPで処理 を行ない, 最終的な結果のみを $\mathrm{PC} に$ 取り込み, OpenGL による三次元表示を行なう。

DSP 内で行なった処理は, (5) 式で行なったIQMを簡略 化し, 近隣 3 近傍 Laplacian フィルタと $2^{3} \times 2^{3}$ 近傍での平 滑化処理である. 今回用いた DSP が, SIMD 処理である列 計算が得意である事から, Laplacian filter, および平滑化ア
ルゴリズムは，図.9, 図.10の様な処理手法で行なっている. Laplacian filterの場合, 得られた画像濃淡情報をレジス夕 $R 1, R 2, R 3$ にそれぞれ取り込み，図.9に示した処理を行な う事により，列内の全ての要素での Laplacian filter が同時 に計算できる。 また，平滑化 (加算) 処理の場合は，図.10に 示すマスクレジスタを事前に作成しておけば，単純な処理 の組合せで処理可能である．この加算処理はトーナメント 方式であり, $N=2^{k}$ 個の通常の足し合わせに必要な計算回 数 $N-1$ を $k$ 回で抑えられる事から, $N$ が大きい場合には 処理速度の軽減が計られる。

システムの空間解像度は, 光学機器の設定に依存するが, 今回の場合, $16 \mathrm{~mm} \times 16 \mathrm{~mm}$ 平方を画像解像度 $256 \times 256$ で処理する事から, $62.5 \mu \mathrm{m} / \mathrm{pixel}$ の解像度を持つ.また奥 行き方向の解像度も光学機器設定之, 取り込み画像枚数に依 存するが, 今回, 可変焦点レンズから $160 \mathrm{~mm}$ の所に $35 \mathrm{~mm}$ 程度の奥行きを持つ物体を置き, 21 枚の画像を取り込み処理 している事から，奥行き解像度は $1.67 \mathrm{~mm}$ である.この時， PZT には電圧を $-30 V$ から $+30 V$ まで $3 V$ 刻みで印加し, 焦 点距離を動かしながら取られた 21 枚の画像の一部を図.11 に示す。ここで用いた測定対象は，円筒形を四段重ねたピ ラミット状の物で, 円筒形の形状はそれぞれ下から, (直径 $\phi=10 \mathrm{~mm} ;$ 高さ $h=10 \mathrm{~mm}),(\phi=7 \mathrm{~mm} ; h=10 \mathrm{~mm})$, $(\phi=4 \mathrm{~mm} ; h=10 \mathrm{~mm}),(\phi=3 \mathrm{~mm} ; h=5 \mathrm{~mm})$ である. また表面にはテキスチャーとして, 高さ $0.8 \mathrm{~mm}$, 幅 $0.4 \mathrm{~mm}$ 程度の英文字フォントが印刷されている。

前述のような処理を施す事により，全焦点画像: 図.12と VR 表示: 図.13がそれぞれ得られた. 全焦点画像自体は適 当であるものの, 奥行き画像は, 平滑化する領域が小さい事, 奥行き方向の解像度 (画像枚数) が少ない事などから, 分散 の大きな結果が得られた。

検証のため, ある距離に設置した画像距離の同じ平面を 撮影し, 得られた奥行き画像距離, 画像番号および PZT への印加電圧，および標準偏差值を図.14に示す。この図 より, 被写体距離と画像番号 (PZTへの印加電圧) は, 可 変焦点レンズの焦点距離変化が飽和しないある範囲におい て比例関係である事が分かる。またその時の標準偏差は, 被写体距離が遠くなるほど大きな值を示し, 被写体距離 $147 \mathrm{~mm}$ で士1 frame $(1.67 \mathrm{~mm})$ であるものが, $161 \mathrm{~mm}$ で は土3frame $(5.01 \mathrm{~mm})$ であることが分かる. 基本的な処理 速度を上げる事が可能であれば，多くの画像を取り込み処 理すると同時に, 局所空間周波数とスムージング処理の領 域の大きさを変える事により, 標準偏差の值の改善が期待 できる。

また現時点まで, 前述のように実時間マイクロVRカメ ラを構築したが, 領域の大きさの設定や, 取り込み画像枚数 に依存するものの, 処理時間は 2 秒間に 1 枚程度の出力し か得られていない. 今後処理の高速化と解像度を向上させ るためには, スマートセンサの DSP 部分の絶対的処理能力 の改善が求められる。 


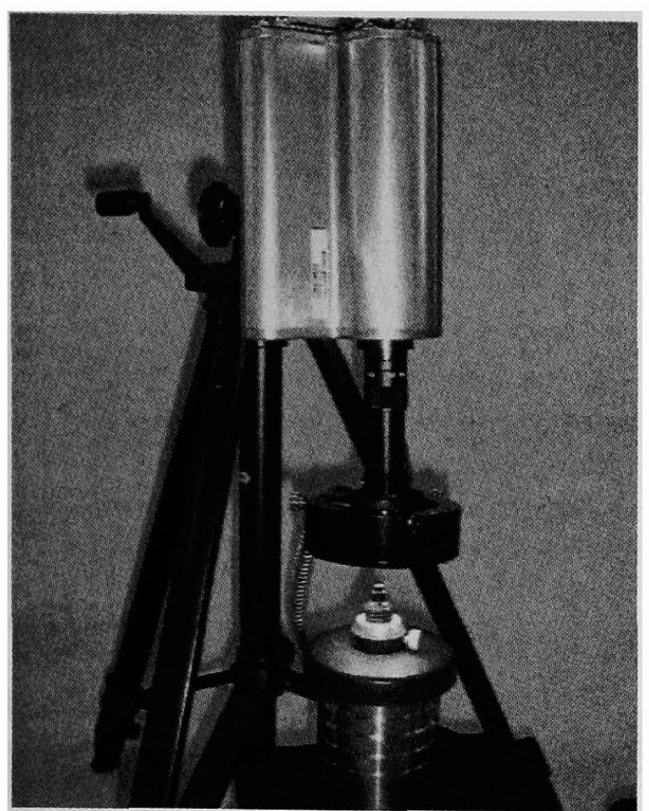

図 8 実時間マイクロVRカメラ概観.

Fig. 8. System Overview.

\begin{tabular}{|c|c|c|c|}
\hline R1 & $\mathrm{I}(\mathrm{i}-1, \mathrm{j}-1)$ & $\mathbf{I}(\mathrm{i}-1, \mathrm{j})$ & $\mathbf{I}(\mathrm{i}-1, \mathrm{j}+1)$ \\
\hline R2 & $\mathbf{I}(\mathrm{i}, \mathrm{j}-1)$ & $\mathbf{I}(\mathrm{i}, \mathrm{j})$ & $I(i, j+1)$ \\
\hline R3 & $\mathbf{I}(\mathrm{i}+1, \mathrm{j}-1)$ & $\mathbf{I}(\mathrm{i}+1, \mathrm{j})$ & $\mathbf{I}(\mathrm{i}+1, \mathrm{j}+1)$ \\
\hline
\end{tabular}

\begin{tabular}{|c|c|c|c|}
\hline$R 4=R 2-R 1$ & $I(i, j-1)-[(i-1, j-1)$ & {$[(i, j)=\{(i-1, j)$} & $I(i, j+1)-\mid(i-1, j+1)$ \\
\hline R5= & {$[(1+1,1,-1)-[(t)-1)$} & $I[(i+1, j)-(i, j)]$ & {$[(i+1, j+1)-(1, j,+1)$} \\
\hline
\end{tabular}

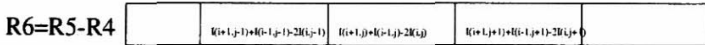

\begin{tabular}{|c|c|c|c|}
\hline R2 & $I(i, j-1)$ & $I(i, j)$ & $I(i, j+1)$ \\
\hline $\mathrm{R} 7=\mathrm{ROR}(\mathrm{R} 2)$ & $I(\mathrm{i}, \mathrm{j}-2)$ & $I(i, j-1)$ & $I(i, j)$ \\
\hline $\mathrm{R} 8=\mathrm{ROL}(\mathrm{R} 2)$ & $I(\mathrm{i}, \mathrm{j})$ & $I(i, j+1)$ & $I(i, j+2)$ \\
\hline
\end{tabular}

\begin{tabular}{|c|c|c|c|}
\hline $\mathrm{R} 9=\mathrm{R} 7-\mathrm{R} 2$ & $1(\mathbf{i}, \mathrm{j}-2)-(\mathbf{i}, \mathrm{j}-1)$ & $I(\mathbf{i}, \mathrm{j}-1)-\mid(\mathbf{i}, \mathrm{j})$ & $1(i, j)-\{(i, j+1)$ \\
\hline $\mathrm{R} 10=\mathrm{R} 8-\mathrm{R} 2$ & $I(\mathbf{i}, \mathbf{j})-[(\mathbf{i}, \mathbf{j}-1)$ & $I(i, j+1)-[(i, j)$ & {$[(i, j+2)-[(i, j+1)$} \\
\hline
\end{tabular}

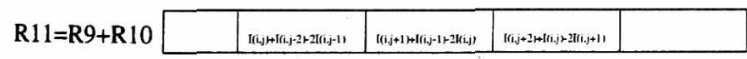

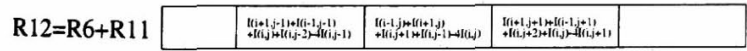

図 9 MAPP2200におけるパラレルラプラシア ンフィルタ処理.

Fig. 9. Parallel Processing for Laplacian Filtering in MAPP2200.

\section{4. まと め}

本論文では, “depth from focus” 理論を用い, 可変焦点
RI \begin{tabular}{|l:l|l:l|l:l|l:l|l:l|l:l|}
\hline$a$ & $b$ & $c$ & $d$ & e & f & g & h & i & j & k & l \\
\hline
\end{tabular}

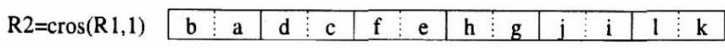

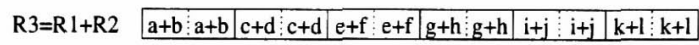

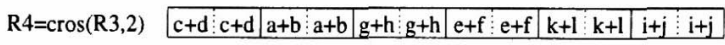
\begin{tabular}{ll|l|l|}
$\mathrm{R} 5=\mathrm{R} 3+\mathrm{R} 4 \quad \mathrm{a}+\mathrm{b}+\mathrm{c}+\mathrm{d}$ & $\mathrm{e}+\mathrm{f}+\mathrm{g}+\mathrm{h}$ & $\mathrm{k}+\mathrm{l}+\mathrm{i}+\mathrm{j}$ \\
\hline
\end{tabular} $\operatorname{cros}(\mathrm{R} 1,1)$

R1 \begin{tabular}{|l|l|l:l|l:l|l:l|l:l|l|l|}
\hline a & b & c & d & e & f & g & h & i & j & k & l \\
\hline
\end{tabular}

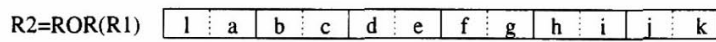

MASK(1) \begin{tabular}{l|l:l|l:l|l:l|l|l|l|l|l|l|}
\hline 0 & 1 & 0 & 1 & 0 & 1 & 0 & 1 & 0 & 1 & 0 & 1 \\
\hline
\end{tabular}

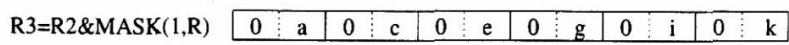

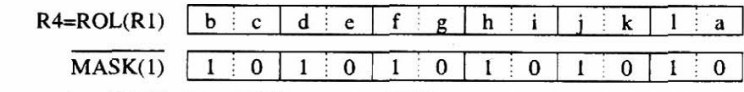

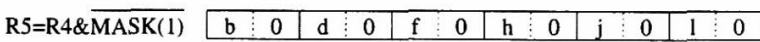

R6=R3 or R5 \begin{tabular}{|l|l|l:l|l:l|l|l|l:l|l:l|}
\hline b & a & d & c & f & e & h & g & j & i & l & $k$ \\
\hline
\end{tabular}

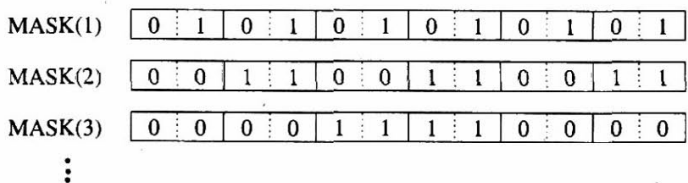

図 10 MAPP2200におけるパラレル平滑化処理.

Fig. 10. Parallel Process for Smoothing in MAPP2200.

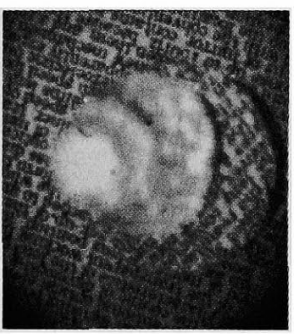

(a)

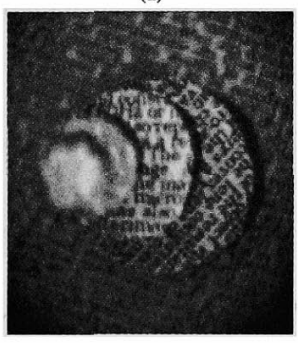

(b)

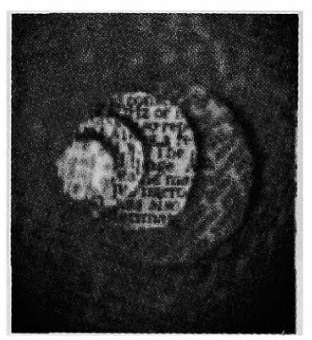

(c)

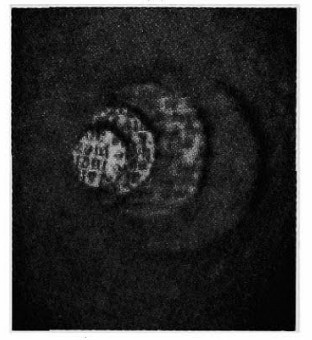

(d)
図 11 単焦点画像例.

Fig. 11. Samples of the Single Focus Images.

レンズとスマートカメラシステムからなる, 三次元マイクロ モデルと全焦点画像を同時に獲得するための実時間マイク ロVRカメラの試作を行なった.

今回は市販のスマートビジョンセンサを用いてシステム 


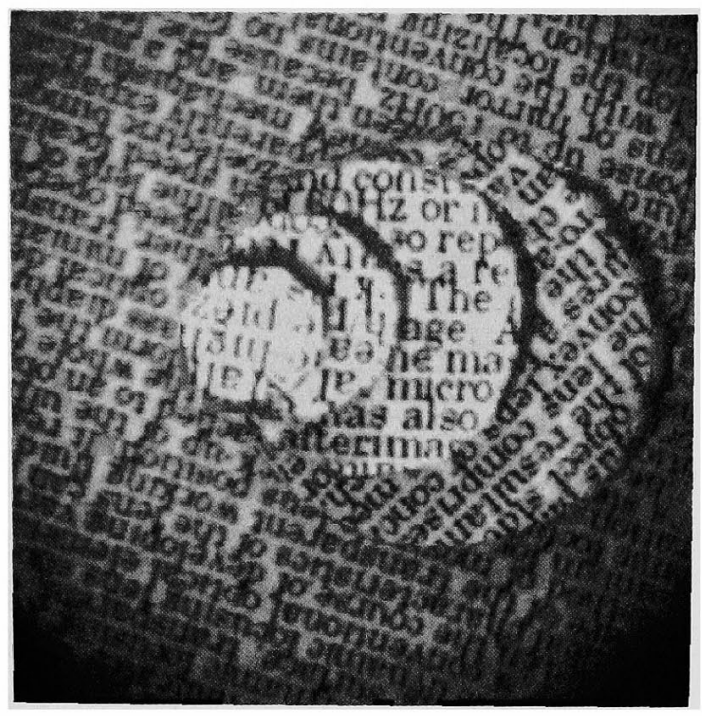

図 12 全焦点マイクロ画像例.

Fig. 12. A sample of the All-in-Focus Image.

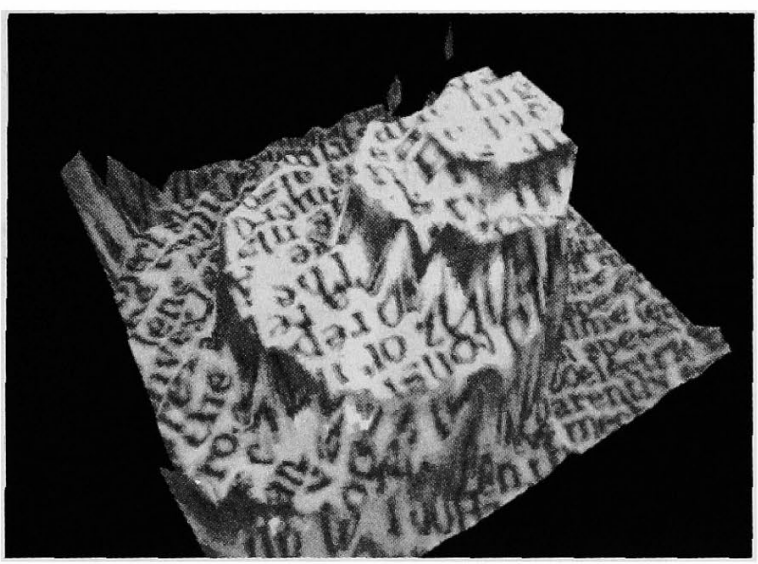

図 13 マイクロ VR 表示例.

Fig. 13. A sample of the Micro VR Environments.

を構築し処理を行なったが, 今後は, 分解解像度の向上を目 指し基本的な処理能力を上げるため処理アルゴリズムの検 証と, より高速な処理能力を実現するシステムの構築を試 みる。

\section{謝辞}

この研究は, 通商産業省工業技術院機械技術研究所と, デ ルフトハイテック株式会社, 川鉄テクノリサーチ株式会社, 株式会社デンソーの共同研究により行なわれた.

また, 本研究の可変焦点レンズの一部は, 通商産業省工業 技術院の産業科学技術研究開発制度に基づく「マイクロマ シン技術の研究開発」の一環として, $\mathrm{NEDO}$ (新エネルギー・ 産業技術総合開発機構) から委託を受けた (財) マイクロマ シンセンターの再委託業務として, (株) デンソーが実施し

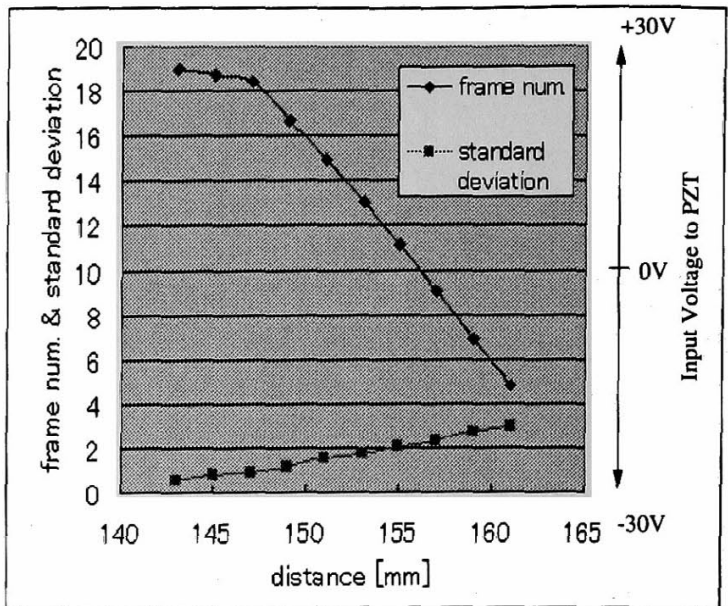

図 14 実時間マイクロカメラシステムの校正.

Fig. 14. Calibration of the Distance on a Micro VR Camera System.

たものである.

(平成 11 年 7 月 23 日受付, 同 11 年 11 月 11 日再受付)

\section{文献}

（1）石原満宏，吉澤徹, “最近の光表面形状計測技術”, O plus E, Vol.20, No.11, pp.1251-1258, 1998.

(2) Masahiro Watanabe and Shree K. Nayer, "Minimal Operator Set for Passive Depth from Defocus", CVPR'96, pp.431-438, 1996.

(3) Shree K. Nayer, Masahiro Watanabe, and Minoru Noguchi, "Real-Time Focus Range Sensor", ICCV'95, pp.995-1001, 1995.

(4) Shree K. Nayer, and Yasuo Nakagawa, "Shape from Focus", IEEE Trans. on PAMI, Vol.16, No.8, pp.824-831, 1994.

(5) A.P.Pentland, "A New Sense for Depth of Field", IEEE Trans. on Pattern Analysis and Machine Intelligence, Vol.PAMI-9, No.4, pp.523-531, 1987.

(6) Michio Miwa, Tomoyuki Oohara, Masahiko Ishii, Yasuharu Koike, and Makoto Sato, "A Method of Far Object Recognition using Depth from Focus", Proc. 3D Image Conference'99, pp.305-307, 1999.

(7) Kazuya Kodama, Kiyoharru Aizawa, and Mitsutoshi Hatori, "Acquisition of an All-Focused Image by the Use of Multiple Differently Focused Images", The Trans. of the Institute of Electronics, Information and Communication Engineering Engineers, D-II, Vol.J80-D-II, No.9, pp.2298-2307, 1997.

（8）児玉和也，大西隆之，相澤清晴，羽鳥光俊，“反復法に基づく複数面 像からの任意焦点画像の生成”, 映像情報メディア学会誌, Vol.51, No.12, pp.2072-2081, 1997

（9）金子卓,多矢信之, 川原伸章, 秋田成行, 服部正, “可変焦点レンズを 用いた長焦点深度視覚機構”, 電気学会マイクロマシン研究会, 1997

(10) Takashi Kaneko, Takahiro Ohmi, Nobuyuki Ohya, Nobuaki Kawahara, and Tadashi Hattori, "A New, Compact and Quick-Response Dynamic Focusing Lens", Transducers'97, 1997.

(11) Bladimir Brajovic and Takeo Kanade, "Sensory Attention: Computational Sensor Paradigm for Low-Latency Adaptive Vision", DARPA Image Understanding Workshop 1997.

(12) Alireza Moini, "Vision Chips or Seeing Silicon", http://www.eleceng.adelaide.edu.au/Groups /GAAS/Bugeye/visionchips/index.html, March 1997.

(13) "User Documentation MAPP2200 PCI System", IVP, 1997.

(14) Sridhar R. Kundur and Daniel Raviv, "Novel Active-VisionBased Visual-Threat-Cue for Autonomus Navigation Tasks", 
Proc. CVPR'96, pp.606-612, 1996.

（15）三宅和夫, “幾何光学”, 共立出版, pp.73-76, 1997.

（16）三輪道雄，大原知之, 石井雅博, 小池康晴, 佐藤誠，“焦点ボケを用 いた遠距㜠物体の推定”, 3D Image Conference '99, pp.305-307, 1999 .

大 場 光太郎（正員） 1964 年 2 月 22 日生. 1991 年 4 月東

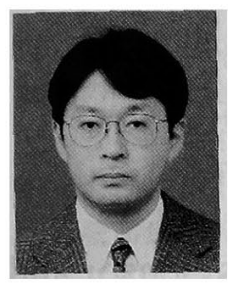
北大学大学院工学研究科機械工学専攻博士課程修 了. 工学博士. 同年 東北大学工学部助手. 1996 年 同講師. 1997 年 通産省 工業技術院 機械技術 研究所 主任研究官, 現在に至る. 1994 年 - 1996 年 $\mathrm{CMU}$ 計算機科学科客員研究員. 主としてコ ンピュータビジョン, HMIに関す石研究に従事.

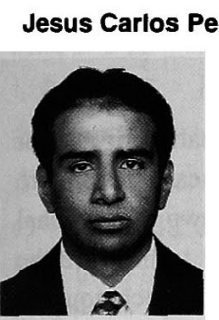

raza Ortega （非会員） 1969 年 12 月 22 日生. 1993 年 9 月 七ラヤ工業大学卒業. 1994 年 機械 技術研究所ロボット工学部, 1995 年 メキシコ電 力会社, 1997 年 グアナファト大学 機械·電気・電 子工学部講師を経て, 1998 年 3 月 同大学 機械. 電気. 電子工学部卒業. 現在, 筑波大学 博士課程 に在学中. IEEE 会員

谷 江和雄 (非会員) 1946 年 11 月 6 日生. 1971 年早稲田

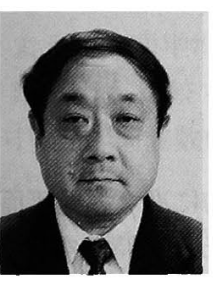
大学大学院理工学研究科修士課程修了. 同年 通 産省 工業技術院 機械技術研究所入所. 現在, 同 所ロボット工学部部長. 筑波大学大学院工学研究 科教授, 早稲田大学理工学総合研究七ンター客員 教授等併任. ロボットの機構と制御の砑究に従事. 日本機械学会, 日本ロボット学会, IEEE ほかの会 員. 工学博士.

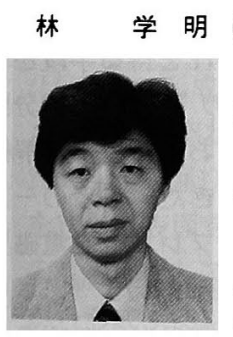

（非会員） 1956 年 7 月 29 日生. 1980 年 6 月 米国 カルフォルニア大学バークレー校卒業. 同年 Delft Instruments NV 社就職. 1981 年 同社日本法人 オールデルフト, 1983 年 同社取締役, 1986 年 同 社代表取締役を経て, 1989 年デルフトハイテッ ク株式会社創業 代表取締役就任, 現在に至る. 応 用物理学, 情報処理工学, スマートセンサ/カメラ の応用開発に従事.

段 木 亮一

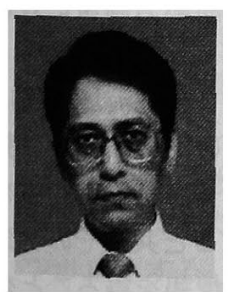

（正員） 1956 年 8 月 14 日生. 1981 年静岡大学工 学部卒業. 川鉄テクノリサーチ株式会社入社, 現 在に至る. 情報処理工学, 電気, 電波, 制御, 通信 工学に従事. 応用数理学会, 電気学会, シミュレー ション学会の各会員.
武 井由

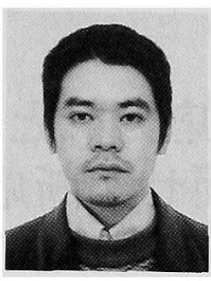

（非会員） 1965 年生. 1992 年 東京工業大学大学 院修士課程修了. 同年 川鉄情報システム (株) 入 社. 1996 年 東京工業大学大学院釉合理工学研究 科物理情報工学専攻入学, 1996 年 同単位取得退 学, 同年 東京工業大学工学部電気電子工学科助手, 長岡技術科学大学電気系助手, 現在に至る. 工学 博士. 計算の複雑さの理論および離散数学の研究 に従事. 電気情報通信学会および LA 会員.
金子

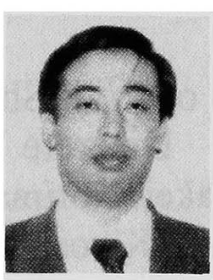

川原伸章（正員） 1957 年 5 月 16 日生. 1983 年 九州大学

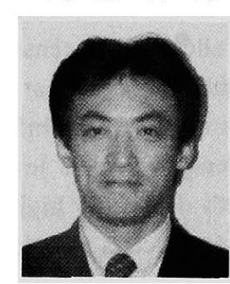
大学院総合理工学研究科修士課程修了. 同年 日本 電装 (株)(現在の (株) デンソー)に入社. 以来, 物 性研究, マイクロデバイス, マイクロマシン研究 に従事. 電気学会, 機械学会各会員. 工学博士. 